\title{
DESAIN ARSITEKTUR KOTA YANG BERIDENTITAS BUDAYA SEBAGAI SEBUAH KONSEP YANG BERKELANJUTAN
}

\author{
Bhakti Alamsyah \\ Jurusan Teknik Arsitektur Universitas Pembangunan Panca Budi \\ Email: hendysaleh29@pancabudi.ac.id
}

\begin{abstract}
ABSTRAK
Kota sebagai cermin dari suatu masyarakat tidak lepas dari keberadaan bangunan-bangunan bersejarah yang merupakan identitas suatu kota. Perencanaan ruang yang tidak melihat karakteristik daerah berupa budaya, rona lingkungan dan budaya setempat dapat menimbulkan bencana langsung maupun tidak langsung bagi penghuninya. Identitas yang dimiliki kota Medan dari segi bangunannya tidak lepas dari arsitektur Melayu. Bangunan arsitektur Melayu bercampur dengan gaya kolonial Belanda. Ini merupakan bukti sejarah bahwa pengaruh Belanda terhadap politik dan ekonomi di Medan sangat besar sekali. Arsitektur rumah Melayu menerapkan konsep lingkungan yang sehat, artinya memanfaatkan alam terbuka sebagai pendukung keserasian dan kesatuan antara bangunan dan lingkungannya. Hepcan mengatakan pemanfaatan jalur hijau dengan menggabungkan antara ruang terbuka dengan ruang tertutup secara langsung ataupun tidak, memiliki nilai ekonomi dan rekreasi dapat merangsang urusan bisnis lokal. Fenomena ini terjadi pada lapangan Merdeka atau Merdeka Walk sebagai wujud implementasi pemanfaatan jalur hijau. Adanya pemanfaatan jalur hijau tidak lepas dari desain arsitektur yang berkelanjutan. Chiotinis mengatakan arsitektur berkelanjutan (sustainable architecture) bertujuan menjaga ketahanan lingkungan, sumber daya alami, ekosistem, yang memberikan nilai sejarah untuk perlindungan dan pemeliharaan yang kesinambungan. Melestarikan salah satu contoh budaya yang kuat dengan menerapkan di dalam wujud bentuk yaitu. penandaan, ruang promosi unsur-unsur yang melekat di dalam sejarah atau dari bangunan
\end{abstract}

Kata kunci: publik space, arsitektur kota, arsitektur berkelanjutan

\section{Pendahuluan}

Istilah lingkungan berhubungan erat dengan keinsyafan manusia terhadap lingkungan yang pada tepat waktu sekarang sudah berubah sama sekali. Keinsafan terhadap lingkungan alam sebagai dasar kehidupan manusia, dihubungkan dengan kesediaan untuk mengusahakan tindakan perbaikan. Pengetahuan atau pengertian keinsyafan masyarakat terhadap lingkungannya akan mempengaruhi realisasi tujuan pada politik lingkungan. Semakin besar keinsafan terhadap lingkungan maka semakin mudah bagi masyarakat untuk mengubah atau berfikir kembali tentang kebiasaan-kebiasaan mereka yang kurang sehat terhadap lingkungannya. Frick mengatakan apabila suatu peristiwa, baik alamiah ataupun non alamiah keseimbangan ekosistem terganggu, sehingga terjadi ancaman terhadap ekosistem 
organisme hidup yang ada disana, maka akan terjadi proses adaptasi pada semua organisme hidup yang terancam tersebut untuk kembali kearah proses yang harmonis dan stabil. Proses ini disebut keseimbangan kembali atau re-equilibrium process (Frick, 1996:47).

Maraknya perbincangan di media massa maupun seminar internasional tentang dampak pemanasan global, urbanisasi, banyaknya bangunan pabrik di perkotaan, banjir, penyakit dimana-mana dan tingginya kematian anak dan ibu merupakan bagian dari perencanaan ruang yang tidak mempunyai konsep berkelanjutan. Perencanaan ruang yang tidak melihat karakteristik daerah berupa budaya, rona lingkungan dan budaya setempat sehingga menimbulkan bencana langsung maupun tidak langsung bagi penghuninya. Bencana yang sering terjadi hampir di setiap kota-kota besar di Indonesia adalah bencana banjir. Pemandangan banjir merupakan hal yang biasa dari tahun ke tahun. Banjir akibat sanitasi yang buruk merupakan tugas bersama untuk menanggulanginya, apalagi tahun 2008 dicanangkan sebagai Tahun Internasional Sanitasi yang dihadapkan berbagai permasalahan kompleks menyangkut lingkungan (Rachmi, 2008).

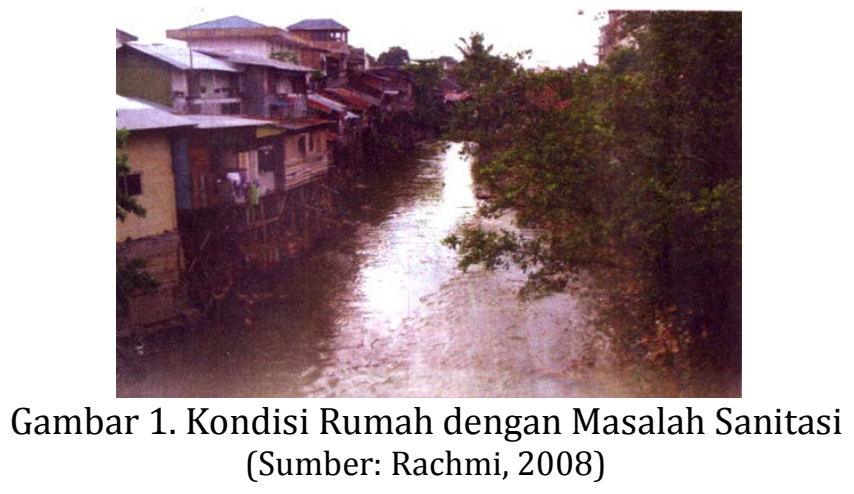

Selain daerah perumahan, masalah sanitasi juga terjadi di jantung Kota Medan seperti di Jalan Cirebon, Pemuda dan Jalan Sisingamangaraja. Daerah ini merupakan pusat bisnis dan perdagangan tetapi masih saja digenangi banjir yang datang setiap tahunnya. Secara umum masalah yang ada di tiga jalan tersebut (Cirebon-Pemuda-Sisingamangaraja) adalah debit air yang melebihi daya tampung saluran air yang ada, sampah yang menyumbat pada saluran air dan tidak adanya jalur hijau sebagai antisipasi terhadap datangnya banjir.

Kasus ini sering terjadi di daerah perkotaan khususnya kota-kota di Sumatera Utara. Bencana langsung berupa ketimpangan pasokan air, ada yang diuntungkan dan ada pihak lain yang kesulitan mendapatkan akses air bersih. Hal ini terjadi akibat pengambilan air tanah yang berlebihan yang dilakukan oleh perumahan mewah atau apartemen yang mulai marak tumbuh di Medan. Perumahan dan villa di Medan khususnya pada Jalan HM. Yamin yang menuju ke Brastagi yang merajalela sulit dikendalikan pertumbuhannya, adalah contoh nyata dari peruntukan lahan yang kurang memperhatikan aspek lingkungan. Belum lagi sinar matahari langsung yang tertutupi oleh tingginya gedung apartemen yang menghalangi bangunan milik penduduk. 


\section{Tinjauan Pustaka}

Sempitnya ruang publik sehingga masyarakat umum tidak mempunyai akses ruang bersama atau bermain bagi anak-anak mereka merupakan bentuk bencana tidak langsung. Whyte mengatakan Public spaces as expression of human endeavour and artifacts of the social world are the physical and metaphysical heart of cities, thus providing channels for movemen, nodes of communication and common ground for cultural activities (Whyte 1980; Lees 1994; Rubenstein 1992; Cat et.al 1995 dirujuk dari Hepcan, 2006: 375).

Keberadaan ruang publik sebagai sarana sosial dan komunikasi untuk melakukan akivitas budaya. Selanjutnya, langkah ini mewakili suatu konsep ruang publik baru yang memperhatikan kepentingan publik yang terus meningkat untuk kelanjutan dan konservasi terhadap lingkungan. Tujuan ideal dari ruang publik agar setiap orang yang bertemu dapat saling bertukar ide. Sempitnya ruang publik mengakibatkan pengkotakan dalam masyarakat, tumbuhnya sifat egois dan individualistik.

Morphologi lingkungan selayaknya mendapat perhatian dalam mendekati sesuatu desain arsitektur bangunan maupun arsitektur kota, sehingga dapat diharapkan akan memiliki perimbangan fisik, dan spasial. Pada tahap desain inilah bisa dibaca nilai eko-arsitekturnya dan tidak semata-mata fisik bangunannya. Nilai ekologis sesuatu desain arsitektur tersebut, yang akan memberi keuntungan bagi publik atas pendayagunaan atau pengolahan sumber-sumber daya alam potensial lingkungan seperti pembuatan jalur hijau (greenways) yang dilakukan oleh Pemda Medan dan disponsori oleh beberapa perusahaan swasta di Medan. Bagi Hepcan (2006: 375) jalur hijau greenways menawarkan beberapa solusi yaitu:

- Ruang terbuka dapat menciptakan infrastruktur yang hijau untuk menghubungkan orang-orang pada suatu tempat

- Perlindungan lingkungan yang alami

- Peningkatan dari wujud-wujud yang berkenaan dengan kota dan nilai keindahan

- Koridor-koridor untuk pejalan kaki lebih ditingkatkan

- Antara ruang terbuka dengan bangunan harus memiliki nilai yang berguna baik dari sisi ekonomis dan rekreasidan meangsang urusan bisnis.

Tarik menarik kepentingan dalam rencana pembangunan baik kepentingan ekonomi maupun lingkungan merupakan hal yang biasa. Kedua kepentingan sebetulnya tidak akan terjadi tarik menarik bila perencana bisa memberikan solusi konkrit dalam memadukan kedua kepentingan tersebut. Jika konsep berkelanjutan (sustainable) diterapkan maka tarik menarik kepentingan tersebut bisa dikurangi. Tiga esensi pembangunan berkelanjutan diantaranya adalah pertama, memenuhi kebutuhan saat ini tanpa mengorbankan kebutuhan yang akan datang. Kedua, tidak melampaui daya dukung lingkungan. Ketiga, mengoptimalkan sumber daya yang ada dengan menyelaraskan antara sumber daya manusia dan pembangunan dengan sumber daya alam.

Arsitektur adalah seni mendesain, membangun dan mewujudkan ide menjadi karya dan termasuk salah satu bidang yang mengubah peradaban setelah bahasa dan filsafat. Ide dan karya arsitek sangat menentukan keadaan lingkungan kedepan termasuk kualitas lingkungan di dalamnya, maka hendaknya setiap ide 
dan karya dalam merencanakan tidak dilihat parsial. Perencanaan wilayah yang sesuai kaidah konservasi tanpa terdesak investasi adalah keharusan, karena kualitas lingkungan saat ini sangat menentukan masa depan lingkungan dan kelangsungan hidup tentunya. Kualitas lingkungan tidak hanya terbatas pada desain rumah, sekolah, tempat kerja melainkan taman, ruang publik dan infrastrukturnya dan semua yang ada pada lingkungan kita. Kemudian dampak bangunan bagi kesehatan penghuni baik kesehatan fisik dan mental anak atau komunitasnya (local community) (Sorrel, 2006 : 254). Dalam desain arsitektur kota, berkelanjutan (sustainable) dimaksudkan adalah adanya program-program jangka panjang yang direncanakan untuk lima atau sepuluh tahun ke depan bagi pengembangan fasilitas kota yang merata hingga ke daerah yang terkebelakang. Atau dalam arti berkelanjutan merupakan karya yang dapat dinikmati atau dipakai untuk generasi penerus.

Menurut Chiotinis (2006: 593) arsitektur berkelanjutan (sustainable architecture) bertujuan menjaga ketahanan lingkungan, sumber daya alami, ekosistem, yang memberikan nilai sejarah untuk perlindungan dan pemeliharaan yang kesinambungan. Melestarikan salah satu contoh budaya yang kuat dengan menerapkan di dalam wujud bentuk yaitu penandaan, ruang promosi unsur-unsur yang melekat di dalam sejarah atau dari bangunan (Chiotinis, 2006: 594)

Prinsip Dasar Desain Arsitektur Berkelanjutan (Lyman, 2007 : 56)

a. keselarasan antara alam dan bangunan

b. mengurangi ketergantungan pencahayaan tiruan, seperti pemakaian energi

c. gunakan bahan material bangunan yang tidak beracun

d. gunakan bahan-bahan baru yang dapat dengan cepat diisi ulang, seperti gabus.

e. kurangi barang sisa timbunan tanah daerah tandus (penggunaan pengomposan)

f. kurangi pengolahan air tanam dengan menggunakan "graywater" atau mengumpulkan air hujan

g. gunakan produk-produk berfungsi baik dan kekal lebih lama

Konsep berkelanjutan pada arsitektur ruang kota (sustainable spaces) tidak hanya mengharuskan pembuat kebijakan bekerjasama dengan para arsitek melihat kembali pabrik-pabrik tersebut. Melihat kembali pabrik berarti melihat juga pembangunan komunitas, ruang publik, arsitektur indah, desain lingkungan, jalur hijau, koneksi komerisial dan layanan seperti aksese internet dengan kecepatan tinggi dan sebagainya.

\section{Hasil dan Pembahasan}

Menurut Hepcan (2006: 375), pemanfaatan jalur hijau adalah dengan menggabungkan antara ruang terbuka dengan ruang tertutup secara langsung ataupun tidak yang memiliki nilai ekonomi dan rekreasi yang dapat merangsang urusan bisnis lokal.

Ini terjadi pada Merdeka Walk, adalah wujud implementasi pemanfaatan jalur hijau yang merangsang urusan bisnis. Di satu sisi ini menguntungkan pihak pebisnis, tapi di lain pihak, ini mengurangi sirkulasi ruang terbuka yang ada sejak jaman Belanda. Namun sekarang ruang terbuka di lapangan Merdeka telah berubah menjadi tempat jajanan orang-orang menengah ke atas (high class). 

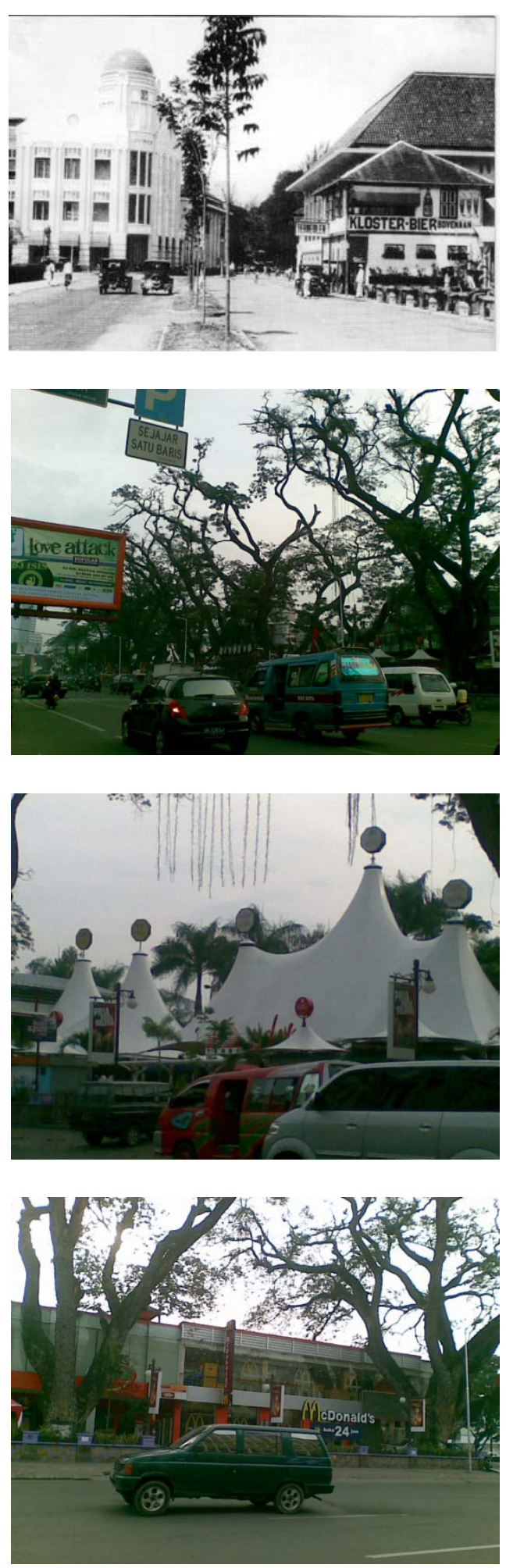

Gambar 2. Jalur Hijau (Greenways) Tahun 1912 di Kawasan Lapangan Merdeka (Sumber: BWS, 2005)

Gambar 3. Jalur Hijau (Greenways) di Kawasan Lapangan Merdeka

Gambar 4. Koridor (greenways) di kawasan Lapangan Merdeka yang disebut Merdeka Walk, kini telah mengambil space untuk tempat jajanan

Gambar 5. Pembangunan tempat jajanan mengganggu tumbuhnya pohon-pohon (greenways) sepanjang jalan kawasan Lapangan Merdeka, kelihatan gersang dan tandus

Ruang publik di pusat kota Medan adalah Lapangan Merdeka. Tadinya berfungsi sebagai tempat senam, olahraga, dan upacara-upacara perayaan HUT kota Medan. Kini tinggal sedikit ruang tersisa akibat tumbuhnya bisnis jajanan di kawasan lapangan Merdeka yang sekarang dijadikan Pemda setempat Merdeka Walk. Keberadaan tempat jajanan tersebut mengakibatkan ruang terbuka semakin sedikit daya saring polusi udara yang dihasilkan semakin banyak. 
Identitas kota Medan tidak lepas dari arsitektur Melayu. Bangunan arsitektur Melayu yang bercampur dengan gaya kolonial Belanda. Arsitektur rumah Melayu menerapkan konsep lingkungan yang sehat, artinya memanfaatkan alam terbuka sebagai pendukung keserasian dan kesatuan antara bangunan dan lingkungannya. Sama dengan konsep asli arsitektur nusantara adalah penyesuaian diri, penyelarasan diri dengan alam, karena alam memberikan kehidupan bagi manusia (Mahyudin, 2003:47). Pendukung keserasian tersebut antara lain dengan menanami halamannya dengan tanaman yang bermanfaat dan bunga untuk mempercantik wajah bangunan atau rumahnya. Berangkat dari konsep tersebut dapat diimplementasikan pada wajah arsitektur kota Medan dengan memanfaatkan ruang terbuka dengan identitas yang dimiliki budaya Melayu itu sendiri.

\section{Kesimpulan}

Perencanaan ruang yang tidak melihat karakteristik daerah berupa budaya, rona lingkungan dan budaya setempat sehingga menimbulkan bencana banjir. Desain arsitektur yang berkelanjutan (sustainable architecture) untuk perlindungan dan pemeliharaan yang kesinambungan.

Identitas kota Medan dengan arsitektur Melayunya haruslah menjadi ciri dari suatu kota. Ditambah dengan percampuan gaya kolonial arsitektur Belanda sebagai pendukung keserasian dan kesatuan antara bangunan dan lingkungannya. Keberadaan tempat jajanan pada ruang terbuka harus diperhatikan keserasiaan dan keseimbangannya dengan lingkungan sekitarnya, karena semakin sedikit ruang terbuka maka semakin meningkat polusi udara dan menjadikan Kota Medan semakin panas.

\section{Daftar Pustaka}

Chiotinis, Nikitas. 2006. The Reguest of Sustainability and Architecture as Cultural Paradigm. Management of Environmental Quality: An Internasional Journal, Vol. 17 No. 5, Emerlad Group Publishing Limited.

Frick, Heinz. 1996. Arsitektur dan Lingkungan. Yogyakarta: Penerbit Kanisius Hepcan, Serif, et.al. 2006. Public Space Networks as a Guide to Sustainable Urban Development And Social Life: A Case Studi of Mugla. Turkey: Internasional Journal of Sustainable Development and World Ecology.

Lyman, Francesca Lyman. 2007. How Green is My City. Academic Research Library.

Sorrel, John. 2006. Healthy Places, Healthy People. The Journal of The Royal Society for The Promotion of Health, Vol. 126 No. 6. Academic Research Library.

Mahyudin, Al Mudra. 2003. Rumah Melayu: Memangku Adat Menjemput Zaman. Yogyakarta: AdiCita Karya Nusa.

Rachmi, Ayu. 2008. Harian Medan Bisnis, Edisi 7 Januari 2008. 